Check for updates

Cite this: Chem. Sci., 2018, 9, 5183

\title{
Oncosis-inducing cyclometalated iridium(III) complexes $\dagger$
}

\author{
Ruilin Guan, ${ }^{a}$ Yu Chen, ${ }^{a}$ Leli Zeng, (D) ab Thomas W. Rees, ${ }^{a}$ Chengzhi Jin, ${ }^{a}$ \\ Juanjuan Huang, ${ }^{a}$ Zhe-Sheng Chen, (D) ${ }^{\mathrm{b}}$ Liangnian $\mathrm{Ji}^{\mathrm{a}}$ and Hui Chao (D) *ac
}

\begin{abstract}
Oncosis is a non-apoptotic form of programmed cell death (PCD), which differs from apoptosis in both morphological changes and inner pathways, and might hold the key to defeating a major obstacle in cancer therapy - drug-resistance, which is often a result of the intrinsic apoptosis resistance of tumours. However, despite the fact that the term "oncosis" was coined and used much earlier than apoptosis, little effort has been made to discover new drugs which can initiate this form of cell death, in comparison to drugs inducing apoptosis or any other type of PCD. So herein, we present the synthesis of a series of mitochondria-targeting cyclometalated Ir(III) complexes, which activated the oncosis-specific protein porimin and calpain in cisplatin-resistant cell line A549R, and determined their cytotoxicity against a wide range of drug-resistant cancer types. To the best of our knowledge, these complexes are the very first metallo-components to induce oncosis in drug-resistant cancer cells.
\end{abstract}

Received 11th March 2018

Accepted 2nd May 2018

DOI: $10.1039 / \mathrm{c} 8 \mathrm{sc} 01142 \mathrm{~g}$

rsc.li/chemical-science

agents), in which a boost in cytotoxicity by glutathione was

\section{Introduction}

Ever since cancer was identified as one of the leading causes of human death, scientists and researchers worldwide have been motivated by the urgency to find a cure for this disease. As the first generation of anticancer drugs, platinum complexes such as cisplatin, oxaliplatin, and carboplatin are unfortunately limited by their severe side effects and, most importantly, inherent or acquired resistance by their target cells..$^{1-3}$ To overcome these limitations, a great deal of research has been done.

One strategy has been to change the metal core of the complex. Different coordination modes or valence states of the metal core have been introduced, including $\mathrm{Pt}(\mathrm{Iv})$ prodrugs, and half-sandwich and cyclometalated complexes. ${ }^{4-9}$ Lippard et al. developed the idea of $\mathrm{Pt}(\mathrm{Iv})$ complexes as anticancer agent candidates, and have recently published a review of new platinum drugs and their design. ${ }^{7}$ Better selectivity towards cancer cells was also achieved by Guo et al., with the introduction of biotin or superparamagnetic iron oxide nanoparticles (MRI

${ }^{a}$ MOE Key Laboratory of Bioinorganic and Synthetic Chemistry, School of Chemistry, Sun Yat-Sen University, Guangzhou, 510275, P. R. China. E-mail: ceschh@mail. sysu.edu.cn

${ }^{b}$ College of Pharmacy and Health Sciences, St. John's University, New York, NY 11439, USA

${ }^{c} M O E$ Key Laboratory of Theoretical Organic Chemistry and Functional Molecule, School of Chemistry and Chemical Engineering, Hunan University of Science and Technology, Xiangtan, 400201, P. R. China

$\dagger$ Electronic supplementary information (ESI) available: Experimental section, NMR, ES-MS, photophysical properties, crystal structure and data, confocal images, cell viability and $\mathrm{IC}_{50}$ values. CCDC 1578910. For ESI and crystallographic data in CIF or other electronic format see DOI: $10.1039 / \mathrm{c} 8 \mathrm{sc} 01142 \mathrm{~g}$ observed. ${ }^{8,9}$

A variety of heavy metal cores including iridium, ruthenium, osmium, titanium, copper, iron, gold, and other metal compounds have also been developed in this field, including some which have made it as far as clinical studies. ${ }^{10-19}$ Sadler et al. developed a series of $\mathrm{Ru}(\mathrm{II})$ complexes with a novel halfsandwich structure and achieved considerable anticancer activity. ${ }^{16}$ Using a different approach, Ma et al. designed Ir(III) complexes as inhibitors of bioactivity and bio-targets, such as H-Ras/Raf-1 protein-protein interactions and tumor necrosis factor- $\alpha .^{17-19}$

Some of the aforementioned groups adopted other approaches, and selective activation of drugs by light is a particularly appealing one. ${ }^{20-24}$ Sadler $e t$ al. reported precisely designed $\mathrm{Pt}(\mathrm{Iv})$ prodrugs, which can sustain the bioactive reducing agent GSH and be photoactivated to $\mathrm{Pt}$ (II) by visible light. ${ }^{20,21}$ Using a similar strategy, Gasser et al. developed a Ru(II) complex, the irradiation of which caused the activation of a protective cage moiety to release the drug. ${ }^{22}$ In another example involving photoactivation, photodynamic therapy (PDT) was employed by Gasser et al. to design Ru(II) polypyridyl complexes $^{23}$ and ruthenium-porphyrin conjugates ${ }^{24}$ as effective photosensitizers and anticancer agents. Although many clinical agents induce apoptosis in order to cause the death of cancer cells, other modes of cell death have also been employed, including necroptosis, autophagy and paraptosis..$^{25-34}$ Using NADH as a cofactor, Sadler $e t$ al. developed a new strategy for anticancer drug design based on the catalytic properties of $\mathrm{Ru}(\mathrm{II})$ compounds, and found the new reductive stress mechanism of cell death. ${ }^{28,29}$ Lippard et al. synthesized two Re(v) oxo 

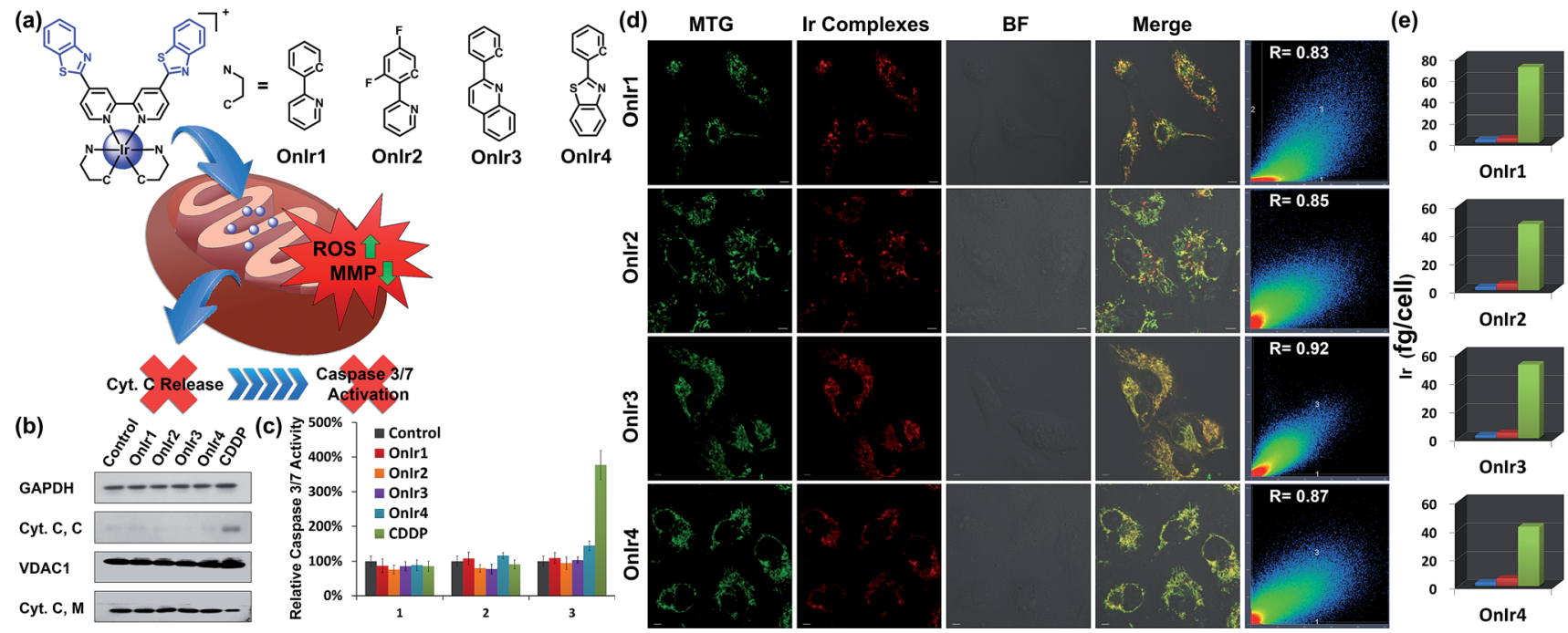

Fig. 1 (a) Chemical structures of $\operatorname{Ir}($ III) complexes. (b) Cyt. C content in the cytosol (Cyt. C, C) and mitochondria (Cyt. C, M). A549R cells were incubated with OnIr1 $(2 \mu \mathrm{M})$, OnIr2 $(2 \mu \mathrm{M})$, OnIr3 $(3 \mu \mathrm{M})$, Onlr4 $(3 \mu \mathrm{M})$, and cisplatin $(150 \mu \mathrm{M})$ for $24 \mathrm{~h}$ and then separated into two cellular portions. (c) Caspase 3/7 activity assay. (d) Confocal images of co-localization assay and (e) ICP-MS results of Ir distribution in the cytosol (blue bar), nucleus (red bar) and mitochondria (green bar). A549R cells were incubated with Ir(III) complexes ( $2 \mu \mathrm{M}, 8 \mathrm{~h}$ ) respectively, and then incubated with MTG for $0.5 \mathrm{~h}$ after being washed with PBS. Scale bar in (d): $10 \mu \mathrm{m}$.

complexes, which induced programmed necrosis, also known as necroptosis, and a Pt(II) complex reported by Guo et al. was proven to induce autophagic cell death in human ovarian carcinoma cells. ${ }^{30,31}$ Gasser et al. discovered that a $\mathrm{Ru}(\mathrm{II})$ polypyridyl complex, a PDT agent they synthesized, can induce either apoptosis or paraptosis depending on the cell cycle phase the cells were in. ${ }^{32}$ New subcellular locations have also been introduced as new targets for therapeutics. Rhee et al. and Ang. et al. presented Ir(III) PDT agents and $\mathrm{Ru}(\mathrm{II})$ complexes which were selectively localized in the endoplasmic reticulum (ER), and caused severe damage to cells. ${ }^{33,34}$

Apoptosis has been thought to be the main death pathway of PCD and it was not until recently that more pathways have been discovered and studied, ${ }^{35}$ and these modes of cell death include the perhaps underestimated oncosis. Since its discovery over a century ago, this potential strategy for the treatment of drugresistant cancers has lain relatively forgotten. ${ }^{36,37}$ Derived from the Greek word "swelling", oncosis is a unique mode of cell death with its characteristic whole cell swelling, accompanied by severe mitochondrial damage, cytoplasmic vacuolization, plasma membrane blebbing and cytoskeletal collapse. ${ }^{37,38} \mathrm{~A}$ surface receptor, porimin, and $\mathrm{Ca}$ ion-related protein calpain were reported as key elements in mediating oncotic cell death..$^{3-41}$

Based on the abundant experience of our group in the design of metal complexes with specific subcellular localization, especially in lysosomes and mitochondria, ${ }^{42-46}$ and because of the fact that mitochondrial dysfunction plays a critical role at a very early stage of cell death, we decided to synthesize a series of mitochondria-targeting cyclometalated Ir(III) complexes. Benzothiazole has been reported to possess considerable anticancer properties, and much research has been carried out aimed at developing benzothiazole containing chemodrugs with high anticancer activity. ${ }^{47-52}$ Therefore, we report in this study a series of iridium(III) complexes with benzothiazole substituted ligands: $\left[\operatorname{Ir}(\text { ppy })_{2}(\text { bbtb })\right]^{+} \quad($ OnIr1 $), \quad\left[\operatorname{Ir}(\text { DFppy })_{2}\right.$ $\left.(\mathrm{bbtb})]^{+}(\text {OnIr2), [Ir(2pq })_{2}(\mathrm{bbtb})\right]^{+}\left(\right.$OnIr3), and $\left[\operatorname{Ir}(\mathrm{pbt})_{2}(\mathrm{bbtb})\right]^{+}$ (OnIr4). The crystalline structure of OnIr3 was also obtained (Fig. 1a and S1-S9广). We tested these complexes with more than ten cancer cell lines, ten drug-resistant cell lines and two normal cell lines, in which considerable cytotoxicity was exhibited as well as good selectivity towards cancer cells and normal cells. These complexes displayed mitochondria-targeting properties and further investigation suggested a relatively unusual death mode as oncosis was activated by OnIr1-OnIr4 in drug-resistant cell line A549R.

\section{Results and discussion}

\section{Subcellular localization}

The subcellular localization of drugs determines the initial interactions between cells and drugs, the study of which, fortunately, is facilitated by the good photophysical properties of the Ir(III) complexes (Fig. S10†). We used A549R, a cisplatinresistant cell line, as a model, to study the behavior of these complexes. The specific cellular target of the complexes was confirmed by a co-localization assay and an ICP-MS assay. As shown in Fig. 1d, the signal of the commercial mitochondrial dye MitoTracker® Green (MTG) correlated well with those of the complexes, giving correlation coefficients between 0.83 and 0.92. In the ICP-MS assay, a majority of the $\operatorname{Ir}($ III) complexes were shown to be localized in the mitochondria (Fig. 1e). Both of the assays confirm that the cellular targets of the $\operatorname{Ir}(\mathrm{III})$ complexes are mitochondria. We also confirmed that the mechanism of cellular uptake of OnIr1-OnIr4 was endocytosis, as shown in Fig. S11. $\dagger$ The stability of OnIr1-OnIr4 in FBS and culture media is also shown in Fig. S12 and S13.† 


\section{Mitochondrial morphological alteration}

Subsequently, we focused on the cellular target of our complexes, mitochondria, the abnormal changes of which would cause severe failure in normal physiological activities. Residing in the mitochondrial inner membrane (MIM), ChChd3 is an abundant protein and essential for maintaining the mitochondrial cristae structure. The loss and reduction of ChChd3 reflects an injury in the MIM, which might result in a breakdown in mitochondrial function and cristae architecture. ${ }^{53}$ A marked decrease in ChChd3 content in a time-dependent manner in the treated cells suggested the occurrence of a traumatic alteration in mitochondria, and all four $\operatorname{Ir}(\mathrm{III})$ complexes displayed similar results (Fig. 2c). Transmission electron microscopy (TEM) experiments were than carried out for the observation of the mitochondrial structure. In the TEM images of untreated A549R cells, the double-membrane structure of the mitochondrion was observed and the mitochondrial cristae were obvious and complex. After treatment with OnIr1, the mitochondrial cristae became smoother, and the entire mitochondrion was dilated and swollen (Fig. 2a), indicating more severe damage and a major loss of mitochondrial membrane potential.

\section{Mitochondrial membrane potential (MMP) and overload of reactive oxygen species (ROS)}

Since one of the main pathways in mitochondria to initiate cell death is the loss of mitochondrial membrane potential (MMP) induced by the overload of reactive oxygen species (ROS), ${ }^{54}$ flow cytometry with JC-1 and dichlorodihydrofluorescein diacetate (DCFH) was performed. The MMP loss of A549R cells would prevent the aggregation of the MMP-dependent mitochondrial dye JC- 1 , indicated by a fluorescence change from red to green, which is shown in Fig. 3a in a time-dependent manner, especially the rise in FITC signals. The cause of MMP loss was tested using DCFH, a ROS reactive reagent. In Fig. 3b, a significant increase in the DCFH signal indicated the over-generation of ROS, also in a time-dependent manner, consistent with the JC-1 results.

\section{ATP depletion and increase in the bcl-2/bax ratio}

Mitochondria are the power plants of the cell, the dysfunction of which can lead to an issue called ATP depletion. ${ }^{55}$ As shown in Fig. 2b, the ATP level of cells after treatment with the $\operatorname{Ir}(\mathrm{III})$ complexes suffered a rapid decrease to less than $35 \%$ of that in the control cells. ${ }^{56}$ As a pair of death-related proteins, the sites of action of which are in mitochondria, bcl-2 and bax are also influenced by the Ir(III) complexes. Western blotting was applied to detect the expression level of these proteins. The content of bcl-2 increased in a time-dependent manner, while that of bax decreased, as shown in Fig. 2a. The ratio of bcl-2/bax increased; note that this pattern is the exact opposite of typical apoptosis, where the expression of bcl-2 would decrease while that of bax would increase, but consistent with a special death mode called oncosis. $^{\text {57-59 }}$ All four $\operatorname{Ir}(\mathrm{III})$ complexes exhibited the same tendency (Fig. 2c). This abnormal phenomenon implied a different death mode from apoptosis.

\section{Release of cytochrome $C$ and caspase $3 / 7$ activation}

After ROS overload and MMP loss we would expect to observe the release of cytochrome $\mathrm{C}$ (Cyt. C) from the mitochondria to the cytosol and then the activation of the caspase family, especially caspase $3 / 7$, which would eventually lead to cell death. ${ }^{60}$ In this study, the cytosol and mitochondria of A549R cells were separated to test their Cyt. C content by western blotting. To our surprise, there was no evidence of Cyt. C release to be observed in the A549R cells (Fig. 1b). In spite of the severe loss of MMP, the content of Cyt. C in the cytosol did not increase and that of the mitochondria did not decrease. The results of (a)
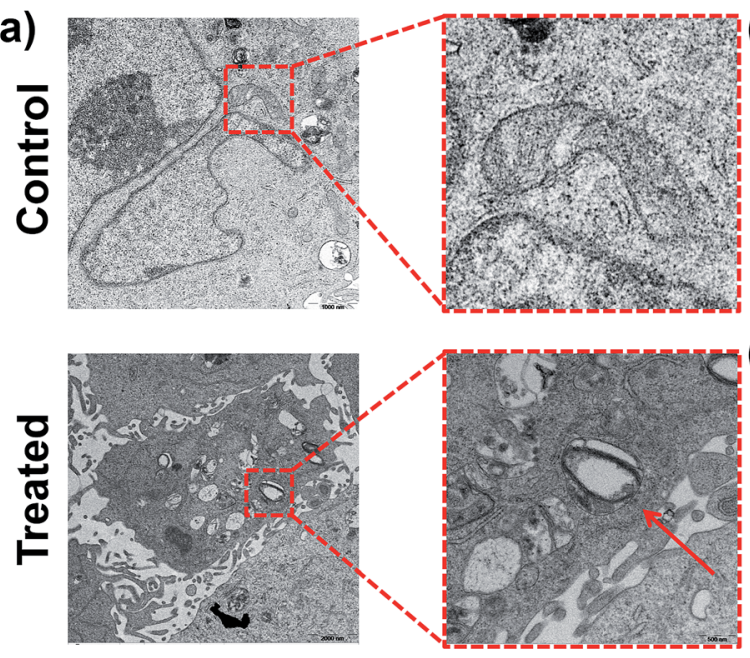

(b)

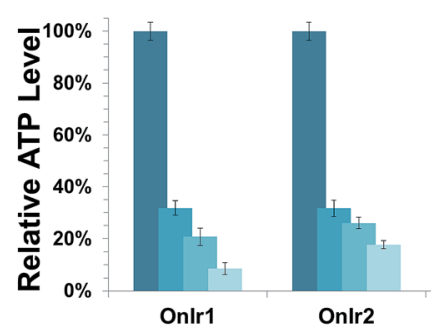

(c)

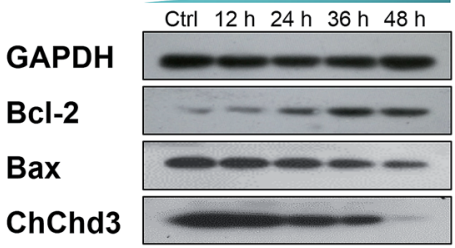

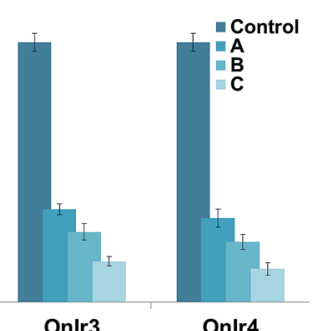

Onlr3 $48 \mathrm{~h}$

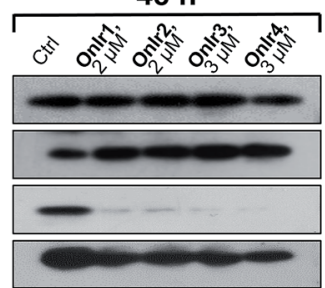

Fig. 2 (a) TEM image of swollen mitochondria. The cells were treated with Onlr1 (1 $\mu M, 24 \mathrm{~h})$. (b) ATP deletion assay for A549R cells incubated with Onlr1-Onlr4 for $48 \mathrm{~h}$. Incubation with Onlr1 and Onlr2 was performed at a concentration of (A) $0.5 \mu \mathrm{M}$, (B) $1 \mu \mathrm{M}$, and (C) $2 \mu \mathrm{M}$; incubation with Onlr3 and Onlr4 was performed at a concentration of (A) $1 \mu \mathrm{M}$, (B) $2 \mu \mathrm{M}$, and (C) $3 \mu \mathrm{M}$. (C) Cellular content of bcl-2, bax and ChChd3 in A549R cells. 
(a)
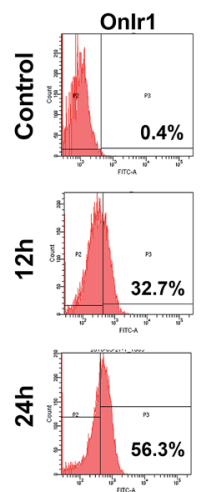

(b)
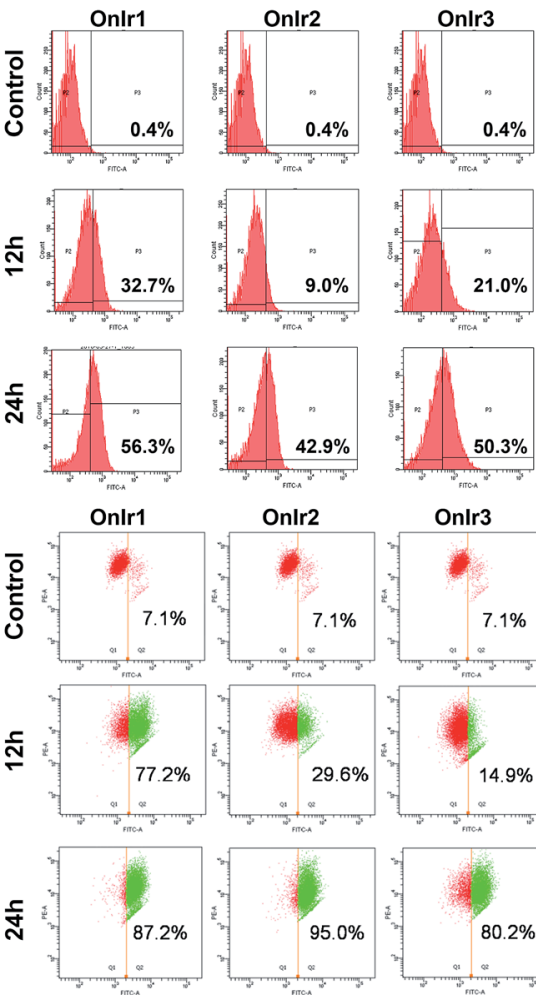

Onlr2
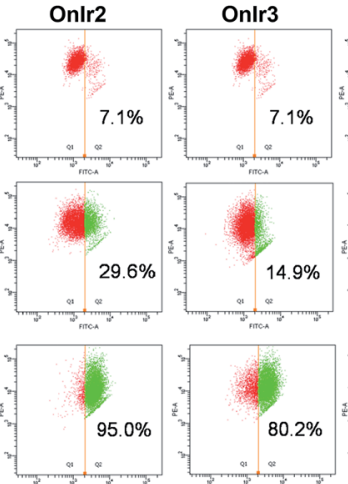

$2 \%$

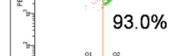

Fig. 3 (a) Flow cytometry results of JC-1 assay and (b) ROS generation assay; A549R cells were incubated with Onlr1 and Onlr2 at a concentration of $1 \mu \mathrm{M}$, while incubation with OnIr3 and Onlr4 was performed at a concentration of $2 \mu \mathrm{M}$.

the whole-cell caspase $3 / 7$ expression level assay agreed with these results, where no obvious increase in the caspase $3 / 7$ level was observed even after incubation with the four $\operatorname{Ir}(\mathrm{III})$ complexes at a concentration of nearly 4 times their $\mathrm{IC}_{50}$ values for one day, while incubation with cisplatin (CDDP) caused an increased signal (Fig. 1c and S14a†). Western blotting was also performed and similar results were obtained (Fig. S16 $\dagger$ ). Caspase inhibitors Ac-DEVD-CHO and Z-VAD-fmk were co-incubated with the $\operatorname{Ir}(\mathrm{III})$ complexes, and no significant changes in cell viabilities were observed (Fig. S14b $\dagger$ ). Therefore, combined with the results of the bcl-2/bax ratio, a different death mode from classic caspase-dependent apoptosis was suggested.

\section{Morphological alterations of the cells}

To clarify which death mode occurred in the process, confocal laser scanning microscopy (CLSM) and TEM were applied to observe the alterations in the A549R cells. The most significant morphological alteration was the vacuolization in cytoplasm, which none of the known forms of apoptosis would cause. During the process, vacuoles generated from lysosomes filled up the entire cytoplasm (Fig. S15†), ${ }^{37}$ taking up most of the space (Fig. 4a), and showing the absence of organelles, as shown in Fig. 4b. As the incubation time increased, the whole cells were swollen and rounded, sometimes detaching from the substrate, and started to bleb (Fig. 4c). This helped us to rule out paraptosis as the mode of cell death, ${ }^{25}$ as neither swelling nor

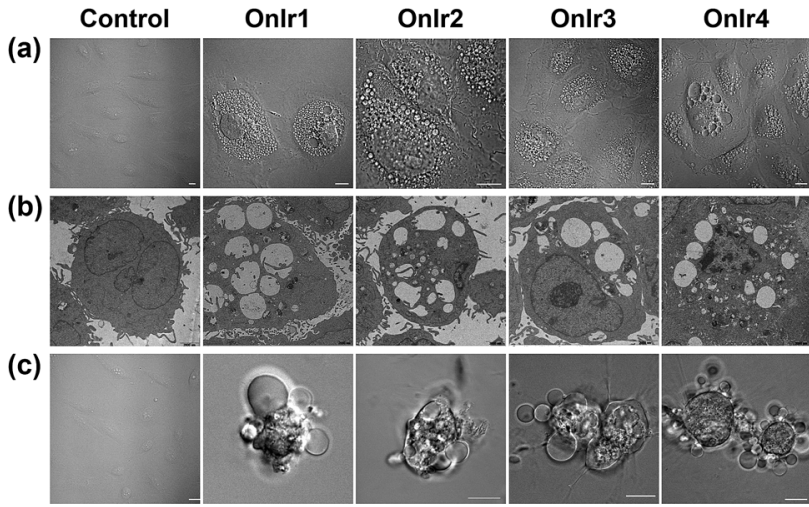

Fig. 4 (a) Confocal images and (b) TEM images of cytoplasmic vacuolization. A549R cells were incubated with Onlr1 (1 $\mu$ M), OnIr2 $(1 \mu M)$, Onlr3 $(2 \mu M)$ and Onlr4 $(2 \mu M)$ for $24 \mathrm{~h}$. (c) Confocal images of plasma membrane blebbing. A549R cells were incubated with Onlr1 $(2 \mu M)$, Onlr2 $(2 \mu M)$, Onlr3 $(3 \mu M)$ and Onlr4 $(3 \mu M)$ for $24 \mathrm{~h}$. Scale bar in confocal images: $10 \mu \mathrm{m}$.

blebbing occurs in paraptosis. Notably, the bubbles around the cells were absolutely clear on the inside, suggesting that there was no process of budding, a typical action of apoptosis, taking place. Another thing worth mentioning is that there was also no sign of interruptions in plasmalemmal continuity in both CLSM and TEM micrographs, a typical feature of necrosis and necroptosis. ${ }^{61}$ The results of co-incubation of autophagy inhibitor 3-methyladenine, paraptosis inhibitor cycloheximide, lysosomal protease-mediated cell death inhibitor leupeptin and necrosis inhibitor necrostatin-1, and the $\operatorname{Ir}(\mathrm{III})$ complexes showed no increase in cell viability (Fig. S14c†). ${ }^{62,63}$ To have a deeper look into it, western blotting was introduced to check the level of LC3, activated during the process of autophagy, ${ }^{64,65}$ RIP3, activated during necrosis and necroptosis, ${ }^{66,67}$ and ERK/ p-ERK, a marker of paraptosis. ${ }^{68}$ Again, no significant changes after treatment with OnIr1-OnIr4 were observed (Fig. S16†). All of the evidence thus far pointed toward oncosis, and so we decided to investigate oncosis more comprehensively.

\section{Cytoskeleton and calpain 1 activation}

The change of the shape and volume of the whole cell also implied a profound impact on the cytoskeleton. Both actin and tubulin were altered during this phase. ${ }^{61,69-71}$ By the use of western blotting, a marked decrease of the basic elements of the cytoskeleton, $\beta$-actin and $\alpha$-tubulin, appeared in a time-dependent manner, ${ }^{72}$ suggesting a possible breakdown and collapse of the cytoskeleton (Fig. 5c). Further research by CLSM and staining with commercial dyes Actin-Tracker Green and Tubulin-Tracker Red allowed the actual visualization of the alterations of actin and tubulin. As shown in Fig. 5a and S17, $\dagger$ control cells have prominent thick actin cables across the whole cells. ${ }^{69}$ After incubation with $0.5 \mu \mathrm{M}$ OnIr1, a punctate pattern of actin appeared, and fewer actin cables were observed in many of the cells. Upon increasing the concentration of OnIr1 to $1 \mu \mathrm{M}$, a lower density of actin fibers was observed as well as fragmentation of the actin filament. We could also see the 
(a)
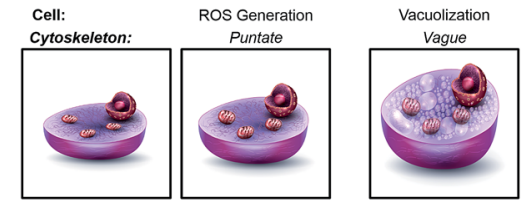

OnIr1
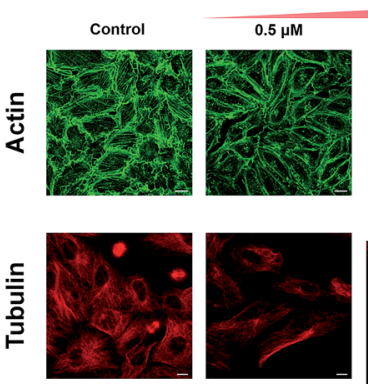

(c)
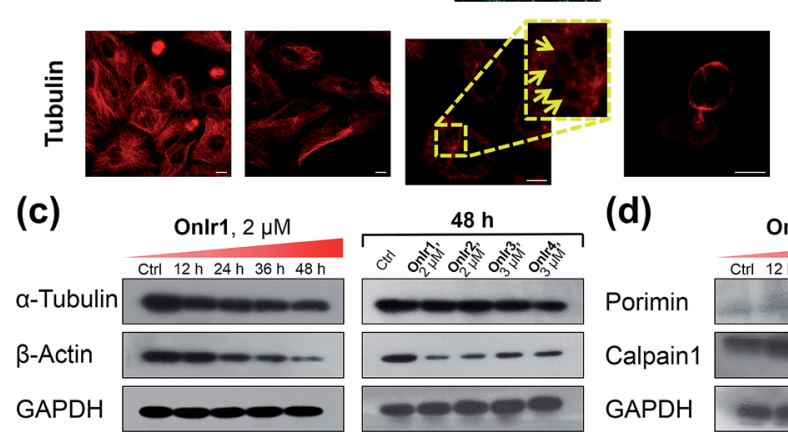

(d)
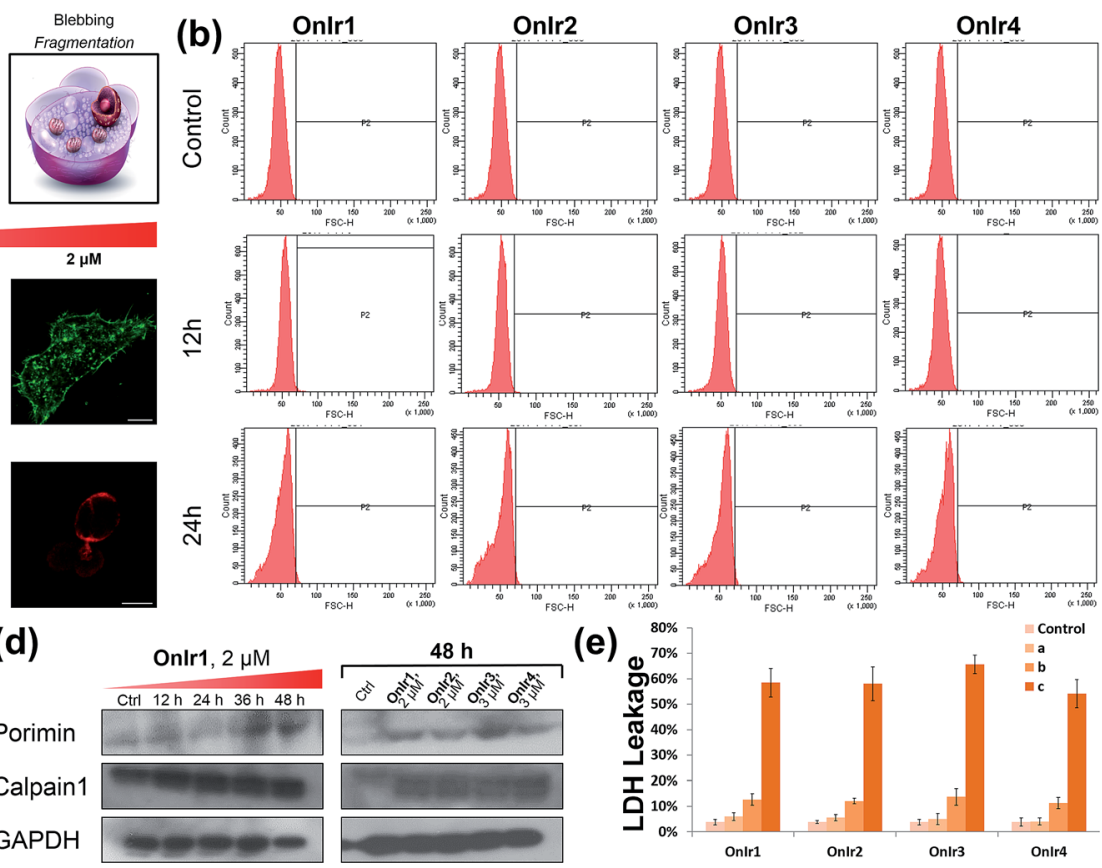

(e)
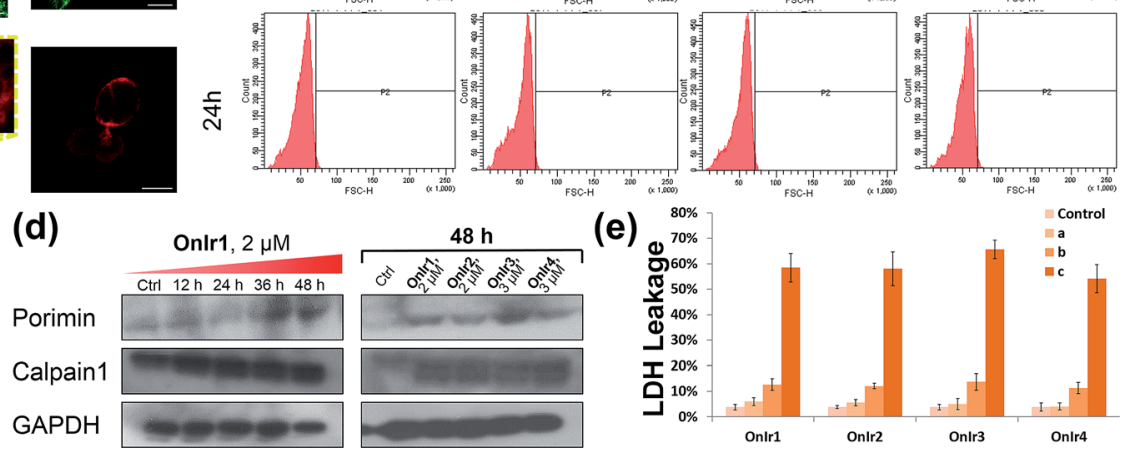

Fig. 5 (a) Actin-Tracker Green and (b) Tubulin-Tracker Red staining of fixed A549R cells pre-treated with Onlr1 for $24 \mathrm{~h}$ in a dose-dependent manner. Confocal images of A549R cells treated with Onlr1 for $24 \mathrm{~h}$. (b) Flow cytometry results of cell volume changes. A549R cells were incubated with Onlr1 $(1 \mu \mathrm{M})$, Onlr2 $(1 \mu \mathrm{M})$, Onlr3 $(2 \mu \mathrm{M})$ and Onlr4 $(2 \mu \mathrm{M})$. Cellular content of (c) $\alpha$-tubulin and $\beta$-actin and (d) porimin and calpain 1 . (e) LDH leakage assay for A549R cells incubated with Onlr1-Onlr4 for $24 \mathrm{~h}$. Incubation with Onlr1 and Onlr2 was performed at a concentration of (A) $0.5 \mu \mathrm{M}$, (B) $1 \mu \mathrm{M}$, and (C) 2 $\mu M$; incubation with OnIr3 and Onlr4 was performed at a concentration of (A) $1 \mu M$, (B) $2 \mu M$, and (C) $3 \mu M$. Scale bar in (a): $10 \mu M$.

interruption of actin fibers by the vacuoles (red arrowhead). After incubation with up to $2 \mu \mathrm{M}$ OnIr1, the pattern of actin cables effectively disappeared, leaving behind the punctate actin, sometimes only some fragments (Fig. S18†), and somehow those fragments managed to slip out of the cell membrane, probably through the bursting of the bubbles, ${ }^{70}$ around which a band of fluorescent stain was observed. ${ }^{69}$ The stain of Actin-Tracker Green faded along with the increase of incubation concentration. Meanwhile, a network of microtubules radiated from the perinuclear centers in control cells, ${ }^{71}$ and the cells underwent mitosis metaphase as shown in Fig. 5a and S19 $\dagger$ with Tubulin-Tracker Red staining. After incubation with $0.5 \mu \mathrm{M}$ OnIr1, the pattern of the microtubules was less rigid. Upon increasing the concentration of OnIr1 to $1 \mu \mathrm{M}$, the loss in length and number of microtubules began and the pattern was vague. A significant interruption of microtubules by the vacuoles (yellow arrowhead) appeared. After further increasing the incubation concentration of OnIr1 up to $2 \mu \mathrm{M}$, the shape of the microtubules became completely loose, and only the carcasses remained both in the cells and the big blebs. Similar to that of Actin-Tracker Green, the stain of TubulinTracker Red decreased with an increase in the incubation concentration of OnIr1, and was completely lost in some of the cells (Fig. S20 $\dagger$ ). These images showed the collapse of the cytoskeleton vividly, and that the breakdown of it could be induced by these Ir(III) complexes in a dose-dependent manner.

Growing evidence indicates that calpains, a calcium-activated protease family, are involved in processes from mitochondrial dysfunction to cytoskeletal collapse. These neutral cysteine proteases were considered to be among the iconic proteins in the procedure of oncotic cell death, and their substrates include cytoskeletal proteins, the activation of which would cause cytoskeletal breakdown. ${ }^{41,72}$ Although the members of the calpain family were considered as cytoplasmic proteins, one of the calpains, calpain 1, was found to be not only rich in, but also navigated by its own structure towards, mitochondria. ${ }^{73}$ The results of western blotting in calpain 1 displayed its activation by the appearance of a new band below the other one after treatment with $\operatorname{Ir}(\mathrm{III})$ complexes, and specifically the treatment with OnIr1 gave rise to the new band in a timedependent manner (Fig. 5d). The impact of calpain activation is profound in oncosis. There are numerous pieces of evidence suggesting that the activation of calpain leads to mitochondrial dysfunction and the breakdown of not only the cytoskeleton but also the plasma membrane. ${ }^{41}$

\section{Plasma membrane permeability and porimin expression}

Since the symbolic phenomenon of oncosis is cell swelling, flow cytometry was employed to measure the enlargement of cell volumes. Apparently, limited by the plasma membrane, a cell cannot swell infinitely, so the peak should not shift entirely to a new volume section. As shown in Fig. 5b, instead of a shift, the shape of the peak representing cell volumes of A549R was changed and tended to a certain extremum, which is the maximum of the control cells, showing an increase in average cell volume. To elucidate how the cells were swollen, we measured the membrane permeability by lactate dehydrogenase 
$(\mathrm{LDH})$ leakage assay. A dramatic increase of signals was observed (Fig. 5d), indicating a large leakage of $\mathrm{LDH}$, and therefore an increase in membrane permeability in a majority of cells. The increase of cell membrane permeability is ascribed to the increase of cell volume.

A surface receptor, porimin (pro-oncosis receptor inducing membrane injury), is supposed to be responsible for the abnormal membrane permeability, which directly causes the iconic whole cell swelling in the process of oncosis, and the activation of porimin is also a marker of oncotic cell death. ${ }^{39,40,74}$ In Fig. 5d, the increase in expression of porimin upon incubation with OnIr2-OnIr4, as well as OnIr1, is demonstrated in a time-dependent manner.

\section{Cytotoxicity against drug-resistant cancer cells}

Now that we had confirmed that the Ir(III) complexes induced a unique death mode, oncosis, which is quite the opposite of apoptosis in many ways, we tried to apply these complexes to fight against cancer cells, especially drug-resistant cancer cells. 11 cancer cell lines from various body parts including lungs, colon, kidneys and liver were tested, along with 10 drug-resistant cell lines and 2 normal cell lines (HL-7702, normal liver cells; HEK 293, normal kidney cells). All four Ir(III) complexes exhibited considerable cytotoxicity in normal cancer cell lines, drug-resistant cell lines and their parental cell lines $\left(\mathrm{IC}_{50}\right.$ values down to $\sim 500 \mathrm{nM}$, Table $\mathrm{S} 3 \dagger)$. The drugs causing resistance included cisplatin, another metal complex like our complexes; mitoxantrone, a type II topoisomerase inhibitor; doxorubicin, a multi-target drug and $\mathrm{As}_{2} \mathrm{O}_{3}$, a classic inorganic nonmetal drug. None of the resistances of these different types of drugs were sufficient for the cancer cells to prevent their death on exposure to the Ir(III) complexes. They also exhibited moderate cytotoxicity towards normal cell lines, but their selectivity towards cancer cells and normal cells can be as significant as $\sim 30$ times the IC $_{50}$ value (OnIr1, HL-7702/A549R).

\section{Discussion}

From subcellular localization to cell membrane injury, we look into some major alterations the treatment with these $\operatorname{Ir}(\mathrm{III})$ complexes led to in the cells. The verification of the death mode caused by certain compounds is often delicate, especially for PCD modes like oncosis, because like any other death modes and pathways, certain phenomena or syndromes of oncosis might be shared with other modes and PCD modes are in a much less acknowledged situation compared with apoptosis. For example, blebbing in cellular membranes could occur both in necrosis and in oncosis; cytoplasmic vacuolization is also a significant feature in paraptosis, etc. Moreover, there are crosstalks between two death modes and that leads to concepts like necroptosis, oncotic apoptosis and even oncotic necrosis, to name a few. In other words, since the word "oncosis" originally means "swelling", every cell death accompanied by whole cell swelling ought to be oncosis, perhaps a crosstalk such as "apoptotic oncosis". When it comes to drug-resistant cancer cells, the situation gets even more complicated. As a matter of fact, after treatment with cisplatin, a classic apoptosis-inducing agent, A549R cells exhibited a sign of autophagy and necrosis with a slight increase in LC3II and RIP3, as shown in Fig. S16. $\dagger$ This situation was somewhat expected, since it was reported that high-dose cisplatin can induce autophagy and necrosis. ${ }^{75,76}$ However, when the pieces of evidence were put together, the fog began to clear, and some of the evidence has been mentioned in previous paragraphs, e.g. the morphological changes of the cells and the bcl-2/bax ratio. Although there is caspase-independent apoptosis which makes the whole caspase 3/7 detection and caspase inhibitor experiments seem less convincing for ruling out this common death mode, ${ }^{77-79}$ apoptosis per se often exhibits other features that are in no way related to what we observed in this paper. While cell shrinkage is a well-known consequence of apoptosis, the exact opposite cell swelling was observed, and cytoplasmic vacuolization is rare in the process of apoptosis. We also carefully checked other PCD modes either by their specific inhibitors or the detection of their characteristic protein expression and activation. Moreover, oncosis matched every single phenomenon perfectly, and most importantly, we demonstrated the activation of calpain 1, which is highly related to oncotic cell death in many aspects, and the expression of porimin, which is supposed to be the marker of oncosis.

The process of oncosis induced by these complexes can be briefly outlined as follows: (1) the complexes entered the cells and localized in the mitochondria; (2) this caused the overgeneration of ROS and (3) the loss of MMP, (4) followed by ATP depletion and an increased ratio of bcl-2/bax, leading to (5) the failure of the ionic pumps resulting in a high cellular membrane permeability and vacuolization from the lysosomes, ${ }^{37}(6)$ rounding and swelling of the cells and blebbing in the plasma membrane, during which (7) a collapse of the cytoskeleton occurred, and finally (8) the bubbles burst and the remainder would experience phagocytosis or inflammation, the very end of an oncotic cell. ${ }^{70}$

\section{Conclusion}

To conclude, we synthesized a series of Ir(III) complexes, OnIr1, OnIr2, OnIr3, and OnIr4, and found that they can target mitochondria and eventually proved that they can induce oncosis in drug-resistant cancer cell line A549R. Finally, we screened the anticancer activity of these oncosis-inducing complexes. They showed $\mathrm{IC}_{50}$ values indicating considerable cytotoxicity against various cancer cell lines and drug-resistant cell lines, with selectivity towards normal cells lines. These results suggest that the unique oncosis-inducing cyclometalated $\operatorname{Ir}($ III) complexes can be potent candidates to fight against drug-resistant cancers.

\section{Conflicts of interest}

There are no conflicts to declare.

\section{Acknowledgements}

This work was supported by the National Natural Science Foundation of China (No. 21525105, 21471164, 21501201 and 
21778079), the 973 Program (No. 2015CB856301), and the Fundamental Research Funds for the Central Universities.

\section{Notes and references}

1 V. Brabec and J. Kasparkova, Drug Resist. Updates, 2005, 8, 131-146.

2 Z. H. Siddik, Oncogene, 2003, 22, 7265-7279.

3 L. Kelland, Nat. Rev. Cancer, 2007, 7, 573-584.

4 T. Zou, J. Liu, C. T. Lum, C. Ma, R. C. Chan, C. N. Lok, W. M. Kwok and C. M. Che, Angew. Chem., Int. Ed., 2014, 53, 10119-10123.

5 N. P. E. Barry and P. J. Sadler, Chem. Soc. Rev., 2012, 41, 32643279.

6 Z. T. Cao, Z. Y. Chen, C. Y. Sun, H. J. Li, H. X. Wang, Q. Q. Cheng, Z. Q. Zuo, J. L. Wang, Y. Z. Liu, Y. C. Wang and J. Wang, Biomaterials, 2016, 94, 9-19.

7 T. C. Johnstone, K. Suntharalingam and S. J. Lippard, Chem. Rev., 2016, 116, 3436-3486.

8 Z. Z. Zhu, Z. H. Wang, Y. G. Hao, C. C. Zhu, Y. Jiao, H. C. Chen, Y. M. Wang, J. Yan, Z. J. Guo and X. Y. Wang, Chem. Sci., 2016, 7, 2864-2869.

9 N. Muhammad, N. Sadia, C. Zhu, C. Luo, Z. Guo and X. Wang, Chem. Commun., 2017, 53, 9971-9974.

10 D. L. Ma, H. Z. He, K. H. Leung, D. S. Chan and C. H. Leung, Angew. Chem., Int. Ed., 2013, 52, 7666-7682.

11 L. Zeng, P. Gupta, Y. Chen, E. Wang, L. Ji, H. Chao and Z. S. Chen, Chem. Soc. Rev., 2017, 46, 5771-5804.

12 R. J. Needham, C. Sanchez-Cano, X. Zhang, I. RomeroCanelon, A. Habtemariam, M. S. Cooper, L. Meszaros, G. J. Clarkson, P. J. Blower and P. J. Sadler, Angew. Chem., Int. Ed., 2017, 56, 1017-1020.

13 Z. G. Yue, W. Wei, Z. X. You, Q. Z. Yang, H. Yue, Z. G. Su and G. H. Ma, Adv. Funct. Mater., 2011, 21, 3446-3453.

14 R. W. Y. Sun and C. M. Che, Coord. Chem. Rev., 2009, 253, 1682-1691.

15 Z. J. Guo and P. J. Sadler, Angew. Chem., Int. Ed., 1999, 38, 1512-1531.

16 T. Sriskandakumar, H. Petzold, P. C. Bruijnincx, A. Habtemariam, P. J. Sadler and P. Kennepohl, J. Am. Chem. Soc., 2009, 131, 13355-13361.

17 L. J. Liu, W. H. Wang, S. Y. Huang, Y. J. Hong, G. D. Li, S. Lin, J. L. Tian, Z. W. Cai, H. M. D. Wang, D. L. Ma and C. H. Leung, Chem. Sci., 2017, 8, 4756-4763.

18 C. H. Leung, H. J. Zhong, H. Yang, Z. Cheng, D. S. Chan, V. P. Ma, R. Abagyan, C. Y. Wong and D. L. Ma, Angew. Chem., Int. Ed., 2012, 51, 9010-9014.

19 T. S. Kang, Z. Mao, C. T. Ng, M. Wang, W. Wang, C. Wang, S. M. Lee, Y. Wang, C. H. Leung and D. L. Ma, J. Med. Chem., 2016, 59, 4026-4031.

20 N. J. Farrer, J. A. Woods, L. Salassa, Y. Zhao, K. S. Robinson, G. Clarkson, F. S. Mackay and P. J. Sadler, Angew. Chem., Int. Ed., 2010, 49, 8905-8908.

21 Y. Zhao, J. A. Woods, N. J. Farrer, K. S. Robinson, J. Pracharova, J. Kasparkova, O. Novakova, H. Li, L. Salassa, A. M. Pizarro, G. J. Clarkson, L. Song, V. Brabec and P. J. Sadler, Chem.-Eur. J., 2013, 19, 9578-9591.
22 T. Joshi, V. Pierroz, C. Mari, L. Gemperle, S. Ferrari and G. Gasser, Angew. Chem., Int. Ed., 2014, 53, 2960-2963.

23 A. Frei, R. Rubbiani, S. Tubafard, O. Blacque, P. Anstaett, A. Felgentrager, T. Maisch, L. Spiccia and G. Gasser, J. Med. Chem., 2014, 57, 7280-7292.

24 C. Mari, V. Pierroz, R. Rubbiani, M. Patra, J. Hess, B. Spingler, L. Oehninger, J. Schur, I. Ott, L. Salassa, S. Ferrari and G. Gasser, Chem.-Eur. J., 2014, 20, 1442114436.

25 S. Sperandio, I. de Belle and D. E. Bredesen, Proc. Natl. Acad. Sci. U. S. A., 2000, 97, 14376-14381.

26 R. R. Ye, C. P. Tan, Y. N. Lin, L. N. Ji and Z. W. Mao, Chem. Commun., 2015, 51, 8353-8356.

27 K. N. Dalby, I. Tekedereli, G. Lopez-Berestein and B. Ozpolat, Autophagy, 2010, 6, 322-329.

28 S. Betanzos-Lara, Z. Liu, A. Habtemariam, A. M. Pizarro, B. Qamar and P. J. Sadler, Angew. Chem., Int. Ed., 2012, 51, 3897-3900.

29 J. J. Soldevila-Barreda, I. Romero-Canelon, A. Habtemariam and P. J. Sadler, Nat. Commun., 2015, 6, 6582.

30 W. J. Guo, Y. M. Zhang, L. Zhang, B. Huang, F. F. Tao, W. Chen, Z. J. Guo, Q. Xu and Y. Sun, Autophagy, 2013, 9, 996-1008.

31 K. Suntharalingam, S. G. Awuah, P. M. Bruno, T. C. Johnstone, F. Wang, W. Lin, Y. R. Zheng, J. E. Page, M. T. Hemann and S. J. Lippard, J. Am. Chem. Soc., 2015, 137, 2967-2974.

32 V. Pierroz, R. Rubbiani, C. Gentili, M. Patra, C. Mari, G. Gasser and S. Ferrari, Chem. Sci., 2016, 7, 6115-6124.

33 J. S. Nam, M. G. Kang, J. Kang, S. Y. Park, S. J. Lee, H. T. Kim, J. K. Seo, O. H. Kwon, M. H. Lim, H. W. Rhee and T. H. Kwon, J. Am. Chem. Soc., 2016, 138, 10968-10977.

34 M. J. Chow, C. Licona, G. Pastorin, G. Mellitzer, W. H. Ang and C. Gaiddon, Chem. Sci., 2016, 7, 4117-4124.

35 L. E. Broker, F. A. Kruyt and G. Giaccone, Clin. Cancer Res., 2005, 11, 3155-3162.

36 P. Weerasinghe and L. M. Buja, Exp. Mol. Pathol., 2012, 93, 302-308.

37 P. Weerasinghe, S. Hallock, R. E. Brown, D. S. Loose and L. M. Buja, Exp. Mol. Pathol., 2013, 94, 289-300.

38 A. A. Peters, S. Y. N. Jamaludin, K. Yapa, S. Chalmers, A. P. Wiegmans, H. F. Lim, M. J. G. Milevskiy, I. Azimi, F. M. Davis, K. S. Northwood, E. Pera, D. L. Marcial, E. Dray, N. J. Waterhouse, P. J. Cabot, T. J. Gonda, P. A. Kenny, M. A. Brown, K. K. Khanna, S. J. RobertsThomson and G. R. Monteith, Oncogene, 2017, 36, 64906500.

39 C. Zhang, Y. Xu, J. Gu and S. F. Schlossman, Proc. Natl. Acad. Sci. U. S. A., 1998, 95, 6290-6295.

40 F. R. Ma, C. H. Zhang, K. V. S. Prasad, G. J. Freeman and S. F. Schlossman, Proc. Natl. Acad. Sci. U. S. A., 2001, 98, 9778-9783.

41 X. Liu, T. Van Vleet and R. G. Schnellmann, Annu. Rev. Pharmacol. Toxicol., 2004, 44, 349-370.

42 K. Q. Qiu, H. Y. Huang, B. Y. Liu, Y. K. Liu, Z. Y. Huang, Y. Chen, L. N. A. Ji and H. Chao, ACS Appl. Mater. Interfaces, 2016, 8, 12702-12710. 
43 H. Huang, B. Yu, P. Zhang, J. Huang, Y. Chen, G. Gasser, L. Ji and H. Chao, Angew. Chem., Int. Ed., 2015, 54, 14049-14052.

44 G. Y. Li, Y. Chen, J. Q. Wang, Q. Lin, J. Zhao, L. N. Ji and H. Chao, Chem. Sci., 2013, 4, 4426-4433.

45 J. Liu, Y. Chen, G. Li, P. Zhang, C. Jin, L. Zeng, L. Ji and H. Chao, Biomaterials, 2015, 56, 140-153.

46 J. Liu, C. Jin, B. Yuan, Y. Chen, X. Liu, L. Ji and H. Chao, Chem. Commun., 2017, 53, 9878-9881.

47 E. Brantley, V. Trapani, M. C. Alley, C. D. Hose, T. D. Bradshaw, M. F. Stevens, E. A. Sausville and S. F. Stinson, Drug Metab. Dispos., 2004, 32, 1392-1401.

48 T. D. Bradshaw and A. D. Westwell, Curr. Med. Chem., 2004, 11, 1009-1021.

49 H. K. Kim, M. K. Kang, K. H. Jung, S. H. Kang, Y. H. Kim, J. C. Jung, G. H. Lee, Y. Chang and T. J. Kim, J. Med. Chem., 2013, 56, 8104-8111.

50 E. Kashiyama, I. Hutchinson, M. S. Chua, S. F. Stinson, L. R. Phillips, G. Kaur, E. A. Sausville, T. D. Bradshaw, A. D. Westwell and M. F. Stevens, J. Med. Chem., 1999, 42, 4172-4184.

51 M. S. Chua, E. Kashiyama, T. D. Bradshaw, S. F. Stinson, E. Brantley, E. A. Sausville and M. F. Stevens, Cancer Res., 2000, 60, 5196-5203.

52 S. Yu, X. Gong and W. Chan, Macromolecules, 1998, 31, 56395646.

53 M. Darshi, V. L. Mendiola, M. R. Mackey, A. N. Murphy, A. Koller, G. A. Perkins, M. H. Ellisman and S. S. Taylor, J. Biol. Chem., 2011, 286, 2918-2932.

54 N. Zamzami, P. Marchetti, M. Castedo, D. Decaudin, A. Macho, T. Hirsch, S. A. Susin, P. X. Petit, B. Mignotte and G. Kroemer, J. Exp. Med., 1995, 182, 367-377.

55 E. M. Mills, D. Xu, M. M. Fergusson, C. A. Combs, Y. Xu and T. Finkel, J. Biol. Chem., 2002, 277, 27385-27392.

56 Q. Huang, R. Zhang, L. y. Zou, X. Cao and X. Chu, PLoS One, 2013, 8, e61345.

57 E. H. Y. Cheng, T. V. Sheiko, J. K. Fisher, W. J. Craigen and S. J. Korsmeyer, Science, 2003, 301, 513-517.

58 S. Cory and J. M. Adams, Nat. Rev. Cancer, 2002, 2, 647-656.

59 P. Weerasinghe, S. Hallock and A. Liepins, Exp. Mol. Pathol., 2001, 71, 89-98.

60 L. M. Dejean, S. Martinez-Caballero and K. W. Kinnally, Cell Death Differ., 2006, 13, 1387-1395.

61 B. F. Trump, I. K. Berezesky, S. H. Chang and P. C. Phelps, Toxicol. Pathol., 1997, 25, 82-88.

62 B. Li, J. Zhao, C. Z. Wang, J. Searle, T. C. He, C. S. Yuan and W. Du, Cancer Lett., 2011, 301, 185-192.
63 M. E. Guicciardi, M. Leist and G. J. Gores, Oncogene, 2004, 23, 2881-2890.

64 N. Mizushima, T. Yoshimori and B. Levine, Cell, 2010, 140, 313-326.

65 D. J. Klionsky, F. C. Abdalla, H. Abeliovich, R. T. Abraham, A. Acevedo-Arozena, K. Adeli, L. Agholme, M. Agnello, P. Agostinis, J. Zschocke and B. Zuckerbraun, et. al., Autophagy, 2012, 8, 445-544.

66 D. W. Zhang, J. Shao, J. Lin, N. Zhang, B. J. Lu, S. C. Lin, M. Q. Dong and J. Han, Science, 2009, 325, 332-336.

67 P. Vandenabeele, L. Galluzzi, T. Vanden Berghe and G. Kroemer, Nat. Rev. Mol. Cell Biol., 2010, 11, 700-714.

68 W. B. Wang, L. X. Feng, Q. X. Yue, W. Y. Wu, S. H. Guan, B. H. Jiang, M. Yang, X. Liu and D. A. Guo, J. Cell. Physiol., 2012, 227, 2196-2206.

69 K. A. Elliget, P. C. Phelps and B. F. Trump, Cell Biol. Toxicol., 1991, 7, 263-280.

70 G. Majno and I. Joris, Am. J. Pathol., 1995, 146, 3-15.

71 P. C. Phelps, K. A. Elliget and B. F. Trump, FASEB J., 1996, 10, A1425.

72 G. Zhang, C. Jiang, Z. Wang, W. Chen, W. Gu and Y. Ding, BioMed Res. Int., 2014, 2014, 682197.

73 R. Badugu, M. Garcia, V. Bondada, A. Joshi and J. W. Geddes, J. Biol. Chem., 2008, 283, 3409-3417.

74 L. F. Liu, Z. H. Qian, Q. Qin, M. Shi, H. Zhang, X. M. Tao and W. P. Zhu, Genet. Mol. Res., 2015, 14, 7481-7489.

75 T. R. O'Donovan, G. C. O'Sullivan and S. L. McKenna, Autophagy, 2011, 7, 509-524.

76 F. R. Khuri, J. Nemunaitis, I. Ganly, J. Arseneau, I. F. Tannock, L. Romel, M. Gore, J. Ironside, R. H. MacDougall, C. Heise, B. Randlev, A. M. Gillenwater, P. Bruso, S. B. Kaye, W. K. Hong and D. H. Kirn, Nat. Med., 2000, 6, 879-885.

77 L. Ravagnan, S. Gurbuxani, S. A. Susin, C. Maisse, E. Daugas, N. Zamzami, T. Mak, M. Jaattela, J. M. Penninger, C. Garrido and G. Kroemer, Nat. Cell Biol., 2001, 3, 839-843.

78 L. Y. Li, X. Luo and X. Wang, Nature, 2001, 412, 95-99.

79 G. Kroemer, L. Galluzzi, P. Vandenabeele, J. Abrams, E. S. Alnemri, E. H. Baehrecke, M. V. Blagosklonny, W. S. El-Deiry, P. Golstein, D. R. Green, M. Hengartner, R. A. Knight, S. Kumar, S. A. Lipton, W. Malorni, G. Nunez, M. E. Peter, J. Tschopp, J. Yuan, M. Piacentini, B. Zhivotovsky and G. Melino, Cell Death Differ., 2009, 16, 3-11. 